\title{
Ebastine, a Mast Cell Blocker Improves Sperm Motility in Asthenospermic Infertile Men
}

\author{
Farzana Deeba*, Jesmine Banu, Shakeela Ishrat, Shaheen Ara Anawary, Nurjahan Begum
}

Department of Reproductive Endocrinology and Infertility, Bangabandhu Sheikh Mujib Medical University, Dhaka, Bangladesh

Email address:

deeba_51@yahoo.com (F. Deeba)

${ }^{*}$ Corresponding author

\section{To cite this article:}

Farzana Deeba, Jesmine Banu, Shakeela Ishrat, Shaheen Ara Anawary, Nurjahan Begum. Ebastine, a Mast Cell Blocker Improves Sperm Motility in Asthenospermic Infertile Men. Biomedical Sciences. Vol. 7, No. 2, 2021, pp. 41-46. doi: 10.11648/j.bs.20210702.11

Received: March 29, 2021; Accepted: April 28, 2021; Published: May 14, 2021

\begin{abstract}
Introduction: The right treatment of male infertility is relatively costly procedure. So we should sincerer about the treatment procedure to evaluate the role of mast cell blocker ebastin in male infertility for the sake of the wellbeing of our people. The study aims to observe and evaluate the effect of Mast cell (MC) blocker Ebastin in the improvement of sperm motility in asthenospermic infertile male. Methods: This was a longitudinal clinical trial study and was conducted in the Infertility Unit outdoor, Department of obstetrics and gynecology, Bangabandhu Sheikh Mujib Medical University, Dhaka. Bangladesh during the period from January 2015 to December 2015. This study was conducted among the male patients and followed Purposive sampling technique. Finally, 334 cases were enrolled in this study. Among the male with abnormal semen parameter 168 patients were Asthenozospermic and 60 patients were combined Oligo-asthenozospermic. Statistical analysis was carried out by using the SPSS 16.0 \& MS-Excel2016. Result: From 334 study people we found in group I, mean sperm total mortality was $24.86 \pm 12.02 \%$ in pretreatment and $34.29 \pm 9.35 \%$ in post treatment. The difference was statistically significant $(p<0.05)$. In group II, mean sperm total mortality was $21.96 \pm 6.17 \%$ in pretreatment and $22.44 \pm 4.81 \%$ in post treatment. The difference was not statistically significant ( $p>0.05$ ). Improved sperm motility was $75.4 \%$ of asthenozospermic male in ebastin group and $19.3 \%$ in placebo group. Which was statistically significant $(\mathrm{p}<0.05)$. In group I, mean rapid progress was found $11.81 \pm 7.76 \%$ in pretreatment group and $19.99 \pm 11.31 \%$ in post treatment. The difference was statistically significant $(\mathrm{p}<0.05)$. In group II, mean rapid progress was found $11.25 \pm 1.67 \%$ in pretreatment group and $11.4 \pm 1.59 \%$ in post treatment. The difference was not statistically significant $(\mathrm{p}>0.05)$. Conclusion: that sperm motility and rapid progress had significantly improved after three months' treatment period with Ebastin than Placebo. Therefore, this study suggested that mast cell blocker ebastin can be helpful than placebo to improve the patients' sperm motility with asthenozoospermia.
\end{abstract}

Keywords: Male Infertility, Mast Cell, Asthenozoospermia, Placebo, Ebastin

\section{Introduction}

Male infertility is a widespread problem and can be referred to a number of causes: apart from hypothalamic-pituitary disorders, a variety of testicular diseases like cryptorchidism, testicular injury, varicocele or testicular tumours have to be considered. In addition, disturbances at the post-testicular level, in particular epididymal dysfunctions, can contribute to disturbed male fertility. Notably, infections and inflammatory disorders of the male genital tract represent a major cause of male infertility and prevalence rates of $10-15 \%$ have been reported among men undergoing andrological examination in infertility clinics. $[1,2]$ Studies demonstrated that orchitis and epidiymo-orchitis due to local or systemic infection as well as noninfectious factors were important etiological reasons for male infertility. [3, 4] Furthermore, spermatogenesis often was disturbed and sperm number and quality irreversibly decrease under chronically testicular inflammatory conditions. However, unfortunately, difficulties occur in the diagnosis of chronic orchitis owing to its mostly asymptomatic course and unspecific diagnostic criteria. The release of tryptase by Mast Cells (MC) in the testis has been associated with fibrotic remodeling in defective spermatogenesis of infertile men and sperm number and quality decrease under chronically testicular inflammatory conditions. [5, 6] Less than $40 \%$ sperm with forward progression or less than $32 \%$ with rapid 
forward progression is called asthenozoospermia. [7] $50 \%$ improvement of motility regarded as improvement. So, the treatment of patients suffering from asthenozoospermia with MC blockers were found to have some improved semen parameters by many authors. [7-9] The right treatment of male infertility is relatively costly procedure. In our country due to ignorance of the patients, lack of sharp cut technology in every level sometime people are misguided by various type of treatment procedures. Maximum people of our country lives below the standard level economical parameter. So we should sincerer about the treatment procedure to evaluate the role of mast cell blocker ebastin in male infertility for the sake of the wellbeing of our people. This study will help our people to save their hard earnings as well as infertility service provider to take proper action in improvement of abnormal semen parameters in the population of low resource country.

The study aims to observe and evaluate the effect of Mast Cell (MC) blocker Ebastin in the improvement of male infertility due to asthenozoospermia.

\section{Objectives}

\section{General objective}

To evaluate the efficacy of Mast cell (MC) blocker Ebastin in the improvement of sperm motility in asthenospermic infertile male.

\section{Specific Objectives}

To describe a demographic chart, personal and family history of the study people.

To find out the effect of ebastin upon sperm motility.

\section{Methodology \& Materials}

This was a longitudinal clinical trial study and was conducted in the Infertility Unit outdoor, Department of obstetrics and gynecology, Bangabandhu Sheikh Mujib Medical University, Dhaka. Bangladesh during the period from January 2015 to December 2015. This study was conducted among the male patients presented to the study place during study period with infertility which is not attributable to any endocrine or urological abnormality and fllowed Purposive sampling technique. A total of 340 infertility patients were included in this study with maintaining inclusion criteria, and among them 6 patients were excluded from the study due to dropout (not came during follow-up). Finally, 167 cases were given Ebastin as group I and 167 patients were given only Placebo as group II.

Inclusion criteria:

All the male patients with infertility with following criteria: Age 25-50 years

Abnormal semen parameter of asthenozospermia.

Exclusion criteria:

1. Age less than 25 years or more than 50 years

2. Abnormalities in reproductive organ

3. Known Hormonal disorder

4. Known Medical disorder

5. Pscho-sexual abnormalities

\section{Urological abnormality}

Finally, 334 cases were enrolled in this study. Among the male with abnormal semen parameter 168 patients were Asthenozospermic and 60 patients were combined Oligo-asthenozospermic. Alternate patient was administered, Tab. Ebastin $10 \mathrm{mg}$ and Placebo twice daily and follow up semen analysis was done at pre fixed schedule after 3 months to analyze the changes that is achieved. Ethical clearance was taken from the local Ethical Committee to perform investigation and study. Statistical analysis was carried out by using the Statistical Package for Social Sciences version 16.0 for Windows (SPSS Inc., Chicago, Illinois, USA) as well as MS-Excel2016. The mean values were calculated by frequencies and percentages. The quantitative observations were indicated by frequencies and percentages. Chi square test was used for categorical variables. Unpaired and Paired t-test was used for continuous variables. $\mathrm{P}$ values $<0.05$ was considered as statistically significant.

\section{Result}

Demographic variable of the patients. It was observed that majority patients belonged to age 31-40 years in both groups, which was $106(63.5 \%)$ in group I and 108 (64.7\%) in group II. The mean age was found $35.8 \pm 5.8$ years in group I and $34.9 \pm 6.1$ years in group II. The difference was not statistically significant $(\mathrm{p}>0.05)$ [Table 1]. Regarding sexual dysfunction, it was observed that no sexual dysfunction was found 155 $(92.8 \%)$ in group I and $160(95.8 \%)$ in group II. Mean staging together was found 5.8 \pm 4.1 years in group I and 5.6 \pm 3.9 years in group II. Mean coital frequency was found $2.8 \pm 0.9$ years in group I and 2.6 \pm 1.1 years in group II. Primary infertility was found $130(77.8 \%)$ in group I and $115(68.9 \%)$ in group II. Mean duration of infertility was found $149(89.2 \%)$ in group I and $161(96.4 \%)$ in group II. Majority $135(80.8 \%)$ patients non smokers in group I and $141(84.4 \%)$ in group II. Smoker was found $32(19.2 \%)$ in group I and $26(15.6 \%)$ in group II. Mean duration of smoking was found $12.0 \pm 6.7$ years in group I and 5.9 \pm 4.7 years in group II. Majority 164 (98.2\%) patients in group I and 166 (99.4\%) in group II were not taken alcohol. The difference was not statistically significant $(\mathrm{p}>0.05)$ [Table 2]. It was observed that majority $115(68.9 \%)$ patients in group I and $128(76.6 \%)$ patients in group II patients had no family history. 34 (20.4\%) patients had DM in group I and $26(15.6 \%)$ in group II. $13(7.8 \%)$ and $9(5.4 \%)$ had infertility in group I and group II respectively. The difference was not statistically significant $(p>0.05)$ [Table 3]. It was observed that mean serum TSH was found $2.3 \pm 1.9 \mathrm{miu} / \mathrm{ml}$ in group I and $2.4 \pm 2.0$ $\mathrm{miu} / \mathrm{ml}$ in group II. Mean prolactine was $8.0 \pm 4.0 \mathrm{ng} / \mathrm{dl}$ in group I and $7.8 \pm 4.1 \mathrm{ng} / \mathrm{dl}$ in group II. Mean serum free testostosterone was found $12.3 \pm 8.5 \mathrm{ng} / \mathrm{dl}$ and $12.1 \pm 8.4 \mathrm{ng} / \mathrm{dl}$ in group I and group II respectively. The difference was not statistically significant ( $p>0.05$ ) [Table 4]. In group I, mean sperm total mortality was $24.86 \pm 12.02 \%$ in pretreatment and $34.29 \pm 9.35 \%$ in post treatment. The difference was statistically significant $(\mathrm{p}<0.05)$. In group II, mean sperm total mortality was $21.96 \pm 6.17 \%$ in pretreatment and $22.44 \pm 4.81 \%$ 
in post treatment. The difference was not statistically significant $(p>0.05)$ [Table 5]. Improved sperm motility was $75.4 \%$ of asthenozospermic male in ebastin group and $19.3 \%$ in placebo group. Which was statistically significant $(\mathrm{p}<0.05)$ [Figure 1]. In group I, mean rapid progress was found
$11.81 \pm 7.76 \%$ in pretreatment group and $19.99 \pm 11.31 \%$ in post treatment. The difference was statistically significant $(\mathrm{p}<0.05)$. In group II, mean rapid progress was found $11.25 \pm 1.67 \%$ in pretreatment group and $11.4 \pm 1.59 \%$ in post treatment. The difference was not statistically significant $(\mathrm{p}>0.05)$ [Table 6].

Table 1. Distribution of the study patients according to age $(N=334)$.

\begin{tabular}{lllll}
\hline \multirow{2}{*}{ Age } & Group I & & Group II & P value \\
\cline { 2 - 5 } & n & \% & n & \% \\
\hline$<30$ & 35 & 21 & 41 & 24.6 \\
$31-40$ & 106 & 63.5 & 108 & 64.7 \\
$41-50$ & 26 & 15.6 & 18 & 10.8 \\
Mean \pm SD & $35.8 \pm 5.8$ & & $34.9 \pm 6.1$ & \\
Range (min-max) & $25-50$ & & $26-45$ & \\
\hline
\end{tabular}

Table 2. Distribution of the study patients by personal history $(N=334)$.

\begin{tabular}{|c|c|c|c|c|c|c|}
\hline \multirow{2}{*}{ Personal History } & & \multirow{2}{*}{$\begin{array}{l}\text { Group I } \\
\text { n } \\
\end{array}$} & \multirow[b]{2}{*}{$\%$} & \multicolumn{2}{|l|}{ Group II } & \multirow{2}{*}{ P value } \\
\hline & & & & $\mathbf{n}$ & $\%$ & \\
\hline \multirow{3}{*}{ Sexual dysfunction } & Impotency & 5 & 3 & 3 & 1.8 & \multirow{3}{*}{0.497} \\
\hline & Premature ejaculation & 7 & 4.7 & 4 & 2.4 & \\
\hline & No & 155 & 92.8 & 160 & 95.8 & \\
\hline \multirow{2}{*}{ Staying together (in years } & Mean \pm SD & \multicolumn{2}{|l|}{$5.8 \pm 4.1$} & \multicolumn{2}{|l|}{$5.6 \pm 3.9$} & \multirow{2}{*}{0.648} \\
\hline & Range (min-max) & $0.2-19$ & & $0.5-11$ & & \\
\hline \multirow{2}{*}{ Coital frequency (in weeks) } & Mean \pm SD & \multicolumn{2}{|l|}{$2.8 \pm 0.9$} & \multicolumn{2}{|l|}{$2.6 \pm 1.1$} & \multirow{2}{*}{0.070} \\
\hline & Range (min-max) & $1-5$ & & $1-5$ & & \\
\hline \multirow{2}{*}{ Type of infertility } & Primary & 130 & 77.8 & 115 & 68.9 & \multirow{2}{*}{0.063} \\
\hline & Secondary & 37 & 22.2 & 52 & 31.1 & \\
\hline \multirow{4}{*}{$\begin{array}{l}\text { Duration of infertility (in } \\
\text { years) }\end{array}$} & $\leq 10$ & 149 & 89.2 & 161 & 96.4 & \\
\hline & $>10$ & 18 & 10.8 & 6 & 3.6 & \\
\hline & Mean \pm SD & $5.15 \pm 3.83$ & & $5.1 \pm 4.1$ & & \multirow{2}{*}{0.908} \\
\hline & Range (min-max) & $0.5-18$ & & $1-15$ & & \\
\hline \multirow{2}{*}{ Smoking } & Yes & 32 & 19.2 & 26 & 15.6 & \multirow{2}{*}{0.386} \\
\hline & No & 135 & 80.8 & 141 & 84.4 & \\
\hline \multirow{2}{*}{ Stick per day } & Mean \pm SD & $6.4 \pm 6.97$ & & $5.9 \pm 4.7$ & & \multirow[t]{2}{*}{0.443} \\
\hline & Range (min-max) & $1-30$ & & $0.5-24$ & & \\
\hline \multirow{2}{*}{$\begin{array}{l}\text { Duration of smoking (in } \\
\text { years) }\end{array}$} & Mean \pm SD & $12 \pm 6.7$ & & $10.9 \pm 5.9$ & & \multirow[t]{2}{*}{0.112} \\
\hline & Range (min-max) & $0.2-30$ & & $0.5-24$ & & \\
\hline \multirow{2}{*}{ Alcohol } & No & 164 & 98.2 & 166 & 99.4 & \multirow[t]{4}{*}{0.311} \\
\hline & Occasional & 3 & 1.8 & 1 & 0.6 & \\
\hline \multirow{2}{*}{ Other drugs } & Yes & 0 & 0 & 0 & 0 & \\
\hline & No & 167 & 100 & 167 & 100 & \\
\hline
\end{tabular}

Table 3. Distribution of the study patients by family history $(N=334)$.

\begin{tabular}{lllll}
\hline \multirow{2}{*}{ Family History } & Group I & \multicolumn{2}{c}{ Group II } \\
\cline { 2 - 5 } & $\mathbf{n}$ & $\mathbf{\%}$ & $\mathbf{n}$ & $\mathbf{2}$ \\
\hline DM & 34 & 20.4 & 9 & 15.6 \\
Infertility & 13 & 7.8 & 9 & 5.4 \\
TB & 5 & 3 & 4 & 2.4 \\
No family history & 115 & 68.8 & 128 & 76.6 \\
\hline
\end{tabular}

Table 4. Distribution of the study patients by endocrine evaluation $(N=334)$.

\begin{tabular}{llll}
\hline Endocrine evaluation & & Group I (n=167) & Group II (n=167) \\
\hline \multirow{2}{*}{ S. TSH (miu/ml) } & Mean \pm SD & $2.3 \pm 1.9$ & $2.4 \pm 2.0$ \\
& Range (min-max) & $0.26-8.95$ & $0.31-9.2$ \\
Prolactine (ng/dl) & Mean \pm SD & $8 \pm 4.0$ & $7.8 \pm 4.1$ \\
& Range (min-max) & $2.2-29.8$ & $2.1-16.2$ \\
S. free testostosterone (ng/d) & Mean \pm SD & $12.3 \pm 8.5$ & $12.1 \pm 8.4$ \\
& Range (min-max) & $2.5-39.6$ & $2.4-31.2$ \\
\hline
\end{tabular}


Table 5. Pretreatment and post treatment difference in sperm motility of isolated asthenospermia $(N=334)$.

\begin{tabular}{|c|c|c|c|c|}
\hline Sperm motility & & Pretreatment & Post treatment & P value \\
\hline Group I (n=84) & $\begin{array}{l}\text { Mean } \pm \text { SD } \\
\text { Range (min-max) }\end{array}$ & $\begin{array}{l}24.86 \pm 12.02 \\
0-39\end{array}$ & $\begin{array}{l}34.29 \pm 9.35 \\
10-82\end{array}$ & 0.001 \\
\hline $\begin{array}{l}\text { Group I }(n=84) \\
\text { P value }\end{array}$ & $\begin{array}{l}\text { Mean } \pm \text { SD } \\
\text { Range (min-max) }\end{array}$ & $\begin{array}{l}21.96 \pm 6.17 \\
0-31 \\
\text { b0.051ns }\end{array}$ & $\begin{array}{l}22.44 \pm 4.81 \\
10-35 \\
\text { b0.001s }\end{array}$ & 0.121 \\
\hline
\end{tabular}

Table 6. Pretreatment and post treatment difference in rapid progress of isolated asthenospermia ( $N=334)$.

\begin{tabular}{lllll}
\hline Rapid progress (\%) & & Pretreatment & Post treatment & P value \\
\hline \multirow{2}{*}{ Group I ( $\mathrm{n}=84)$} & Mean \pm SD & $11.81 \pm 7.76$ & $19.99 \pm 11.31$ & 0.001 \\
& Range (min-max) & $0-32$ & $10-60$ & 0.052 \\
Group II ( $\mathrm{n}=84)$ & Mean \pm SD & $11.25 \pm 1.67$ & $11.4 \pm 1.59$ & \\
P value & Range (min-max) & $7-13$ & $8-16$ & \\
\hline
\end{tabular}

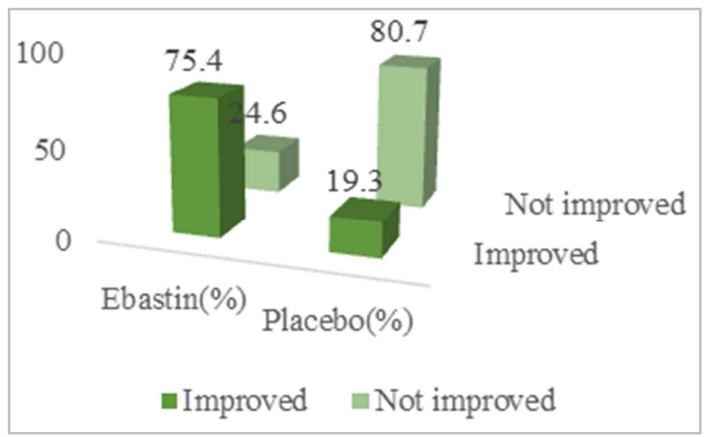

Figure 1. Bar diagram showing improvement of sperm motility (Ebastin $N=114)$; (Placebo $N=114$ ).

\section{Discussion}

All the male patients with infertility with age belonged to $25-$ 50 years, abnormal semen parameters i.e. asthenozoospermia and not attributable to any endocrine or urological abnormality were enrolled in this study. Age less than 25 years or more than 50 years, abnormalities in reproductive organ, known Hormonal disorder, known Medical disorder, psychosexual abnormalities and urological abnormality were excluded from the study. The present study findings were discussed and compared with previously published relevant studies. Mast cells (MCs), play a key role in the inflammation, hypersensitivity and fibrosis, are as well normally present in the testes. [6-11] Roaiah [12] study suggest that there is a prominent increase in the number of testicular MCs in the testes of infertile men which may disrupt spermatogenesis. Also, it was reported that increased numbers of MCs have been associated with different types of infertility, including asthenospermia. $[12,13]$ Therefore, some of male factor infertility problems could possibly diminished if such pathogenesis agent would greatly reduce using drug that block $\mathrm{MC}$ mediator release. In this present study it was observed that majority patients belonged to age 31-40 years in both groups, which was $106(63.5 \%)$ in group I and 108 (64.7\%) in group II. The mean age was found $35.8 \pm 5.8$ years in group I and $34.9 \pm 6.1$ years in group II. The difference was not statistically significant $(p>0.05)$. Saharkhiz [14] found the male were aged 23-40 years of mean age 32.8 years, which is consistent with the current study. Similarly, Multigner [15] and Cayan [16] showed the mean age of the infertile male patients were 32.0 years varied from 22 to 47 years and $34.5 \pm 7.2$ years varied from 24 to 49 years respectively. Similar, age range also observed by Roaiah ${ }^{12}$ and Hussein [17] in their respective studies. On the other hand El-Karaksy [18] showed $64.0 \%$ were in more than 40 years and $36.0 \%$ were in under 40 years, which is higher with the current study, The higher age range maybe due to geographical variations, racial, ethnic differences and different lifestyle may have significant influence to identified their infertility. Prostatitis causes substantial morbidity to men, through associated urinary symptoms, sexual dysfunction, and pelvic pain; however, $90 \%$ to $95 \%$ of cases have an unknown etiology obtained by Ellem. [19] Regarding sexual dysfunction, no sexual dysfunction was found $155(92.8 \%)$ in group I and $160(95.8 \%)$ in group II. Mean staging together was found 5.8 \pm 4.1 years in group I and 5.6 \pm 3.9 years in group II. Mean coital frequency was found $2.8 \pm 0.9$ years in group I and $2.6 \pm 1.1$ years in group II. The difference was not statistically significant $(\mathrm{p}>0.05)$. In this current study it was observed that majority $135(80.8 \%)$ patients nonsmokers in group I and 141 $(84.4 \%)$ in group II. Smoker was found $32(19.2 \%)$ in group I and $26(15.6 \%)$ in group II. Mean duration of smoking was found $12.0 \pm 6.7$ years in group I and $5.9 \pm 4.7$ years in group II. Majority $164(98.2 \%)$ patients in group I and $166(99.4 \%)$ in group II were not taken alcohol. The difference was not statistically significant $(p>0.05)$. Seminal mast cells showed higher frequency among smokers compared with nonsmokers, suggesting an aetiological relationship between smoking and mast cell abundance in infertile patients, and therefore an indirect relationship between smoking and infertility. This supports the studies that establish smoking as having an adverse effect on fertility, especially on progressive sperm motility, irrespective of total amount of cigarettes smoked per day. [20, 21] In this study it was observed that majority 115 (68.9\%) patients in group I and $128(76.6 \%)$ patients in group II patients had no family history. 34 (20.4\%) patients had DM in group I and $26(15.6 \%)$ in group II. 13 (7.8\%) and $9(5.4 \%)$ had infertility in group I and group II respectively. The difference was not statistically significant ( $p>0.05$ ). In this present study it was observed that mean serum TSH was found $2.3 \pm 1.9 \mathrm{miu} / \mathrm{ml}$ in group I and $2.4 \pm 2.0 \mathrm{miu} / \mathrm{ml}$ in group II. Mean prolactine was $8.0 \pm 4.0 \mathrm{ng} / \mathrm{dl}$ in group I and $7.8 \pm 4.1 \mathrm{ng} / \mathrm{dl}$ in group II. Mean serum free testostosterone was found $12.3 \pm 8.5$ $\mathrm{ng} / \mathrm{dl}$ and $12.1 \pm 8.4 \mathrm{ng} / \mathrm{dl}$ in group I and group II respectively. The 
difference was not statistically significant $(p>0.05)$. Cayan [16] showed the serum testosterone values was $5.5 \pm 2.6 \mathrm{ng} / \mathrm{mL}$ varied from 1.7 to $12.6 \mathrm{ng} / \mathrm{mL}$, which is lesser with the present study. Ketotifen's (Mast cell blocker) androgenic effects on male infertility, associated with asthenospermia, have been reported by Olivia and Multigner [22] Studies have also shown that it may counteract the ability of MCs to trigger an inflammatory response. It is worth mentioning that the number of MCs sometimes increases more than normal in the testicular tissue of infertile men. [23] In another study Schill also suggested that ketotifen (Mast cell blocker) can be more helpful to improve the patients' sperm count and sperm motility with idiopathic asthenospermia. In this present study it was observed that in group I, mean sperm total mortality was $24.86 \pm 12.02 \%$ in pretreatment and $34.29 \pm 9.35 \%$ in post treatment. The difference was statistically significant $(\mathrm{p}<0.05)$. In group II, mean sperm total mortality was $21.96 \pm 6.17 \%$ in pretreatment and $22.44 \pm 4.81 \%$ in post treatment The difference was not statistically significant $(p>0.05)$. Saharkhiz showed the mean sperm motility increased significantly from $16.7 \%$ to $21.4 \%$ after ketotifen (Mast cell blocker) treatment $(\mathrm{p}<0.001)$. This sperm motility improvement was more pronounced in the primary infertility cases $(p<0.05)$. In $52.0 \%$ of infertile men's semen, the percentage of sperm motility was increased from $5 \%$ to $35 \%$ and this sperm motility improvement was also observed in $33 \%$ of necrospermia $(0 \%$ motility) cases. In group I, mean rapid progress was found $11.81 \pm 7.76 \%$ in pretreatment group and $19.99 \pm 11.31 \%$ in post treatment. The difference was statistically significant $(\mathrm{p}<0.05)$. In group II, mean rapid progress was found $11.25 \pm 1.67 \%$ in pretreatment group and $11.4 \pm 1.59 \%$ in post treatment. The difference was not statistically significant ( $p>0.05$ ). In this study improved sperm motility was $75.4 \%$ of asthenozospermic male in ebastin group and $19.3 \%$ in placebo group. Which was statistically significant $(p<0.05)$. Saharkhiz found $52 \%$ of infertile men's semen, the percentage of sperm motility was increased from $5 \%$ to $35 \%$ and this sperm motility improvement was also observed in $33 \%$ of necrospermia ( $0 \%$ motility) cases. Multigner $^{15}$ observed $23.6 \%$ patients presented a sperm concentration of $<20 \times 10^{6} / \mathrm{mL}$ and a sperm motility of $<50 \%$ in $65.4 \%$, which is comparable with the current study. Matsuki [24] investigated the effect of ebastine, a mast cell blocker, on semen quality in idiopathic asthenozospermic men reporting $66.7 \%$ of the patients had improved semen quality. Olivia and Multigner carried out a study to assess the efficacy of daily administration of ketotifen (Mast cell blocker), on the semen quality of men with leukocytospermia and unexplained infertility. They noticed that ketotifen diminished the white blood cell count in semen and so the sperm motility have been dramatically improved. Moreover, the number of morphologically normal spermatozoa was more pronounced at 8 weeks of treatment and these changes remained until at least 4 weeks after stopped of ketotifen (Mast cell blocker) treatment. Ketotifen (Mast cell blocker) was used several years ago for treating patients with idiopathic oligozoospermia and asthenozoospermia (independent of the presence of leukocytospermia). This led to a very moderate but statistically significant improvement in sperm count and sperm motility. Matsuki showed that the mast cell blocker ebastine significantly improved semen quality in idiopathic asthenozospermic. Hibi et al. (2001) reported that tranilast improved semen parameters in severe asthenozoospermia, but not for long-term administration. Matsuki ${ }^{24}$ observed the effect of mast cell blocker (ebastine) on semen quality was evaluated in 15 idiopathic asthenozospermic males and $66.7 \%$ showed definite improvement in the semen quality. It would appear that mast cell blocker (ebastine) significantly improves semen quality in men with idiopathic asthenozoospermia. Nagai [25] had shown that the number of mast cells in testicular tissue was increased and the ratio of mast cell subtypes (chymase and tryptase) was changed in idiopathic asthenozospermia. Yamamoto [26] prescribed randomly mast cell blocker (tranilast) or placebo for 3 months' infertile males with severe idiopathic asthenozospermia, showing significant improvement in semen parameters.

Limitations of the study

The present study was conducted at a very short period of time. Small sample size was also a limitation of the present study. Therefore, in future further study may be under taken with large sample size. Indeed, it seems that further research is necessary to identify the precise capacity of Ebastin to improve quality of semen parameters and whether this $\mathrm{MC}$ blocker has effects on the cumulative outcome of reproduction.

\section{Conclusion and Recommendations}

From this paper we found that sperm motility and rapid progress had significantly improved after three months' treatment period with Ebastin. Therefore, this study suggested that mast cell blocker ebastin can be helpful to improve the patients' sperm motility of asthenospermic infertile men. Further community based or multicentre, double blind placebo controlled studies can be undertaken by including large number of patients and Ebastin can be given to the asthenozoospermic men before intrauterine insemination (IUI) or ART cycles of treatment.

\section{References}

[1] Dohle GR, Colpi GM, Hargreave TB, Papp GK, Jungwirth A, Weidner W 2005. EAU guidelines on male infertility. Eur. Urol, vol. 48 , no. 5 , pp. $703-711$.

[2] Tuttelmann F, Nieschlag E 2009. Classification of andrological disorders. In: Andrology: Male Reproductive Health and Dysfunction. Nieschlag E, Behre HM, Nieschlag S (Eds). Springer, NY, USA, pp. 90-96.

[3] Schuppe HC, Meinhardt A, Allam JP, Bergmann M, Weidner W, Haidl G 2008. Chronic orchitis: a neglected cause of male infertility? Andrologia, vol. 40, no. 2, pp. 84-91.

[4] Haidl G, Allam JP, Schuppe HC 2008. Chronic epididymitis: impact on semen parameters and therapeutic options. Andrologia, vol. 40, no. 2, pp. 92-96.

[5] Pejler G, Abrink M, Ringvall M, Wernersson S 2007. Mast cell proteases. Adv. Immunol, vol. 95, pp. 167-255. 
[6] Pejler G, Ronnberg E, Waern I, Wernersson S 2010. Mast cell proteases: multifaceted regulators of inflammatory disease. Blood, vol. 115, no. 24, pp. 4981-4990.

[7] Schill WB, Schneider J, Ring J 1986. The use of ketotifen, a mast cell blocker, for treatment of oligo-and asthenozoospermia. Andrologia, vol. 18, no. 6, pp. 570-573.

[8] Yamamoto M, Hibi H, Miyake K 1994. Appearance of spermatozoon after administration of mast cell blocker to a patient with azoospermia. Hinyokika Kiyo, vol. 40, no. 6, pp. 541-543.

[9] Hibi H, Kato K, Mitsui K 2001. The treatment with tranilast, a mast cell blocker, for idiopathic oligozoospermia. Arch. Androl, vol. 47 , no. 2 , pp. 107-111.

[10] Winters BR, Walsh TJ 2014. The Epidemiology of Male Infertility. Urol Clin N Am, vol. 41, pp. 195-204.

[11] Chakraborty S, Bonthu N, Swanson BJ, Batra SK 2011. Role of mucins in the skin during benign and malignant conditions. Cancer Lett, vol. 301, pp. 127-41.

[12] Roaiah MM, Khatab H, Mostafa T 2007. Mast cells in testicular biopsies of azoospermic men. Andrologia, vol. 39, no. 5, pp. 185-189.

[13] Haidl G, Duan YG, Chen SJ, Kohn FM, Schuppe HC, Allam JP 2011. The role of mast cells in ale infertility. Expert Rev Clin Immunol, vol. 7, pp. 627-34.

[14] Saharkhiz N, Nikbakht R and Hemadi M 2013. Ketotifen, a mast cell blocker improves sperm motility in asthenospermic infertile men. J Hum Reprod Sci, vol. 6, no. 1, pp. 19-22.

[15] Multigner, L 2006, 'Ketotifen improves sperm motility and sperm morphology in male patients with leukocytospermia and unexplained infertility', Fertil Steril, vol. 85, pp. $240-3$.

[16] Cayan S, Apa DD, Akbay E 2002. Effect of fexofenadine, a mast cell blocker, in infertile men with significantly increased testicular mast cells. Asian J. Androl, vol. 4, no. 4, pp. 291294.

[17] Hussein MR, Abou-Deif ES, Bedaiwy MA 2005. Phenotypic characterization of the immune and mast cell infiltrates in the human testis shows normal and abnormal spermatogenesis. Fertil. Steril, vol. 83, no. 5, pp. 1447-1453.

[18] El-Karaksy A, Mostafa T, Shaeer OK, Bahgat DR, Samir N 2007. Seminal mast cells in infertile asthenozoospermic males. Andrologia, vol. 39, no. 6, pp. 244-247.

[19] Ellem SJ, Wang H, Poutanen M, Risbridger GP 2009. Increased endogenous estrogen synthesis leads to the sequential induction of prostatic inflammation (prostatitis) and prostatic pre-malignancy. Am. J. Pathol, vol. 175, no. 3, pp. 1187-1199.

[20] Hassa H, Yildirim A, Can C, Turgut M 2006. Effect of smoking on semen parameters of men attending an infertility clinic. Clin Exp Obstet Gynecol, vol. 33, pp. 19-22.

[21] Mostafa T, Tawadrous G, Roaih MMF, Amer M, Ashour S, Aziz A 2006. Effect of smoking on seminal plasma ascorbic acid in infertile and fertile males. Andrologia, vol. 38, pp. 221224.

[22] Oliva A, Multigner L 2006. Ketotifen improves sperm motility and sperm morphology in male patients with leukocytospermia and unexplained infertility. Fertil. Steril, vol. 85, no. 1, pp. 240-243.

[23] Moskovtsev SI, Willis J, White J, Mullen JB 2007. Leukocytospermia: Relationship to sperm deoxyribonucleic acid integrity in patients evaluated for male factor infertility. Fertil Steril, vol. 88, pp. 737-40.

[24] Matsuki S, Sasagawa I, Suzuki Y 2000. The use of ebastine, a mast cell blocker, for treatment of oligozoospermia. Arch. Androl, vol. 44, no. 2, pp. 129-132.

[25] Nagai T, Takaba H, Miyake K, Hirabayashi Y, Yamada K 1992. Testicular mast cell heterogeneity in idiopathic male infertility. Fertil. Steril, vol. 57, no. 6, pp. 1331-1336.

[26] Yamamoto M, Hibi H, Miyake K 1995. New treatment of idiopathic severe oligozoospermia with mast cell blocker: results of a single-blind study. Fertil. Steril, vol. 64, no. 6, pp. $1221-1223$ 